\title{
THE IMPACT AND ROLE OF MEDIA FOR PEACE AND HUMAN SECURITY DURING COVID -19 CRISES
}

\author{
Shivali Kapoor \\ Ph.D Research Scholar, Department of Political Science, \\ University of Jammu, Jammu \\ Manish Dubey \\ Research Scholar, Amity School of Communincation, \\ Amity University Madhya Pradesh, Gwalior
}

\begin{abstract}
The main objective of the study is to investigate the impact of Covid-19 on the peace and security of the human beings. The epidemic of corona virus disease 2019 (COVID-19) has created a global crisis that has had a deep impact on our lives. Every country faces the spieling of necessities based either on focusing economic, geographical or process related reality for peace and human security. This paper discussed the Covid-19 as threat to peace and security. The paper focuses on key issues relating to the concepts of peace, human security at the time of corona virus pandemic and the role of media. The issues include the social media as one of the pillars which aware the society at the rural level to urban level during the pandemic and also helps to maintain peace and security in the world. The paper also presents the importance of media in 2020 year and the associated debate regarding how the different organizations can help to overcome the covid-19 crises as well as role of media to achieve the "peace and human security globally, much-talked-about".
\end{abstract}

Keywords: Media, Covid -19 crisis, Peace, Human Security, Impact, Threat.

\section{INTRODUCTION}

"Covid-19 anywhere is a threat to people everywhere" (Harri, 2020). As 2020 starts, many ongoing and new peace processes were undergoing internationally. In the ending of 2019 and beginning of 2020, local health authorities in Wuhan, China determined that an outbreak of pneumonia like symptoms resulted from a novel Corona Virus labeled Covid-19 (Huang C, Wang Y Li X, et al., 2020). On 11thof March 2020 the World Health Organization (WHO) declared that the spread of covid-19 has resulted in a global pandemic (WHO, March 2020). The emergence of new pathogen has become the biggest global threat in the world. The global spread of this infection has become a source of worry and panic. The general public takes help from media to control the spread of disease. (Anwar A, Malik M, Raees V, et al., 2020). The media is the major source of delivery of information of this pandemic to the population of the world (Wang PW, 2020).Every country faces the spieling of necessities based either on focusing economic, geographical or process related reality for peace and human security. The 1994 global Human Development Report argued that the concept of security has "for too long been interpreted narrowly: as security of territory from external aggression, or as protection of national interests in foreign policy, or as global security from a nuclear holocaust. It has been related more to nation states than to people" (UNDP, 1994). Though peace and security are necessary goals for every country but the role of 'media' for achieving these goals is very important. As in current scenario the corona virus pandemic is dangerous in 21st century. Now a days media whether electronic media or print media both doing his role efficiently to aware the society against the consequences of corona virus pandemic (Anwar A, Malik M, Raees V, et al., 2020). United Nations also play a delinquent role for the safeguard of all the Nations. This is the testing time of the United Nations, state government and particularly the media about how these three pillars of the world used to overcome the corona virus pandemic. No one exactly knows about when the nobel corona virus started infecting people, but it is fair to say that corona virus pandemic has been with us from the last eight months. During the initial stage it has no self-identity but as the time has lapse it creates his identity all over the world. In the present time every person 
even the minor knows about corona virus and the place where it has emerged, which is Wuhan city in China. The outbreak of respiratory syndrome in the city of Wuhan in China, because of coronavirus becomes spot light since December 2019 (Li et al., 2020) probably related to a wholesale seafood market in Huanan (Y. Chen, Liu, \& Guo, 2020). The media is the only source which has created the identity of corona virus over the world about how pandemic it is and aware the world against the guidelines that has been issued by the World Health Organization (WHO) from time to time. Consuming news by social media is like a two edged sword. On one side, it is fast, cheap and easy accessed, but on other side it may be fake information. The fast spread of the fake information has a negative impact on the peace of human beings and society, (Raj A, Goswami, 2020). The scientific and medical information regarding the corona virus is required for the policy makers to better respond and take necessary measures for the protection of general public. The major objectives of the study are: (a) to investigate the impact of Covid-19 on the peace and security of the human beings. (b) to analyse the mediating effects to aware, control and prevent the Covid-19 pandemic and to maintain the peace and security of the individual.

The rest of the paper is organized as follows. Section two provides the literature review. Section three presents the concepts and threats to peace and human security during Covid-19. Section four explains the positive as well as negative impact of media during Covid-19 pandemic.

\section{REVIEW OF LITERATURE}

In the past the world experienced various pandemics like Plague (165 AD), The Spanish flu(1918-1920), The Asian flu(1956-1958), Ebola(2017) and many others. The Covid-19 is a recent pandemic and its literature is still limited. To the analysis of this research, the literatures used are various studies conducted on different pandemics in the past that has affected the world largely. Also studies conducted on different pandemics are used to correlate with the Covid-19 pandemics and also works on media's role in disseminating information to maintain peace and security during pandemic are similarly reviewed. Previous analysis on media coverage of disease focuses on four different frames that are education, statistics, transmission and prevention (Pratt, Ha, \& Pratt, 2002).

The outbreak of Ebola virus disease in African countries has become the headlines in media. The wide coverage of media helps many countries in fighting the disease and raised awareness among people. Even though unbalanced media coverage by some media has created panic in the world. So, the nature of the media coverage has affected the peace and security of the human beings. The misinformation by non-professionals on social media like twitter, facebook etc intensified Ebola fear and anxiety among people of all over the world (Yusuf I, Yahaya S, \& Qabil S, 2015).After the outbreak of Influenza A (H1N1) in 2009, media provides informative facts about the nature of H1N1 and other prevention measures (Sandman, 2009). The less or no communication becomes hurdle in the attempt to prevent the spread of infectious disease (Brandt et al., 2011). The people due to ignorance refused to get vaccination which is required to prevent the spread of flu at that time.

However studies shows that during pandemics media also create panic and fear among the people. An analysis of Brazilian TV news channel come to the conclusion that media leads to 'Scenario of Panic' (Da Silva Medeiros and Massorani 2010). The study of British newspaper shows that the little evidences of media 'over hyping' the pandemic (Hilton and hunt, 2010).

The spread of previous pandemic is still not fully known. The researcher identified the challenges and measures taken by the government to curtail the pandemic but less attention is given to the peace and security of the people and role of social media. Media changes society (Di Maggio, 2011). Media leads to the dissemination of information to the large number of people (Bowd, 2016). Thus the pandemic has made the people to be active on social media to keep up with the world. Now during the Covid-19 pandemic, media is accessible to almost every person in the world with the advent of cheap smart phones, TVs etc. Media plays a vital role in dissemination of information. These are the fast means of communication such as Facebook, Twitter, Youtube and Whatsaap etc. 
where the individuals remain all time connected and impacts their thinking and behaviour. The positive information encourage for positive actions. The situation of Covid-19 put persons in isolation. Social media is the only way for spending time and reduces the chances of depression (Lobato $\mathrm{E}$, Powell M., Padilla L, \& Holbrook C, 2020).This research explains the role of media from the context of maintaining peace and security of people during the pandemics. It further explains the misinformation through media leads to panic and fear among people. The media also helps to implement different decisions made by the Nations (Obi-Ani, Chinenye A \& Mathias C Isiani, 2020). The Covid-19 and the lockdown policies imposed by the government made the people totally dependent on media. Media has changed the way of people in perceiving and responding to the Covid-19 pandemic as compared to the different pandemics in the past (Rudrani G, Health Promotion, 2020).

\section{THEORETICAL FRAMEWORK}

The world faces the peace and human security challenges during Covid-19 pandemic. Moreover, tensions are raised due to supply chain disruptions, food insecurity and rising unemployment that leads to political unrest Media has contributed lot in this global pandemic Covid-19 and therefore been part of the problem. Media helps in maintaining peace and security by modifying the people's behaviour and attitude. A study published in 2016, (yan Q. et al), found how media reports changed the people's response and affects in controlling the emerging disease. In 2009, during the HINI pandemic, the media reports raised both awareness as well as fear among people. In the one hand it helps people to use defensive methods and on the other hand it creates panic in the society through inappropriate information. This indicates that impact of media during the pandemic is a two directional approach. After the pandemic of SARS 2003-2004, the media impact model was designed which was inconclusive on the overall impact of media (Anwar A., Malik M., 2020). Thus there is a need to expand the model and studying its effects. The public awareness increased manifold with the advancement of technology and internet access by common man leads to the better implementation of public health measures. The different studies on the role of media during the pandemic were conducted, showing a stronger reaction. The media's role to maintain peace and security during covid19 pandemic is thoroughly discussed in this study to give new impetus to the existing literature.

\section{METHODOLOGY}

Explanatory and analytical methods have been adopted in the study of relevant material for writing of this article. The study examines the pros and cons of media towards maintaining peace and security of human beings during corona virus. The information for this research is collected from primary and secondary sources. The primary data for this research were collected thorough online messages, Blogs, Personal discussions telephonic conversations and governmental reports. The respondent gives their opinion freely and without any hesitation and pressure. On the other hand the secondary sources of this research are collected through journals, articles, online material, newspapers and magazines etc. Wherever possible, diagrams, charts, tables and graphics have also been provided, explained and analysed.

\section{Understanding Peace}

"If you want peace, you must prepare for war" (Vegetius, $4^{\text {th }}-5^{\text {th }}$ century).The concept of peace and its nature have changed since time immemorial. Semantics of peace have also emerged anew. Peace is generally regarded as such state of affairs in which there is no war or fighting, a state of peace of mind, freedom from civil disturbance, a state harmony in personal relation etc. The definitions of peace can vary with religion, social and cultural milieu or purpose of an act and study. Peace is usually defined either in a positive or a negative sense. This distinction was first formulated and popularised by Johan Galtung in an editorial to the initial number of the "Journal of Peace and Peace Research". Johan Galtung defines "negative peace as the absence of violence which is equated with the absence of war- and positive peace as the integration of human society" (Galtung Johan, 1964). The concept of negative peace according to Johan Galtung defined as absence of war. Adler talks of positive peace as belonging to idealists who potray peace as some kind of utopia "incorporating the improvement of politics and human nature, social justice, morality, international organisation and law, 
and human progress" (Aron Raymond, 1966), whereas Kenneth Boulding sees positive peace as signifying ... "a condition of good management, orderly resolution of conflict, harmony associated with mature relationships, gentleness, and love" (Boulding Kenneth, 1978).

Peace is also regarded as a constant crusade for wholesome and happy life for all individuals in the politics among nations. The modern world is facing a multidimensional crisis like poverty, hunger, environmental degradation over militarization, nuclear proliferation, overdevelopment and underdevelopment resulting in maldevelopment, in the form of overuse of nature and the one more new crises on current year in the shape of virus covid-19 in public life. Corona virus started the disruption of peace from the first day of the 2020 year and till today millions of people infected by the virus and about more than half of the millions of people lost their life because of the deadly virus. If there is no peace no one can move forward to achieve the greatest possible heights in one's lifetime.

The world, indeed, is filled with war, terrorism and massive sufferings despite there being so many technological inventions for development but none of the technological inventions and other political and diplomatic efforts has been able to establish permanent and long lasting peace. Peace is considered as highest value for humanity to achive some supreme end. Consider: "Peace at any price"(Lamartine, 1820), "Peace is more important than all justice" (Luther Martin, 1530).

\section{Concept of Human Security}

Human security concept emerged as a holistic paradigm of human development by Mehbub ul Haq, and Amartya Sen cultivated at United Nations Development Programme (UNDP). Global Human Development Report (HDR) was the first major international document to articulate human security in conceptual terms with excellent proposals for the application of policies. Mehbub ul Haq and several others involved explored the topic at a North-South Roundtable called the 'Economics of Peace', held in Costa Rica in January 1990.The Roundtable produced a clear statement that, the post-cold war world needed "a new concept of global security," with the "orientation of defence and foreign policy objectives changed from an almost exclusive concern with military security to a broader concern for overall security of individuals from social violence, economic distress and environmental degradation." This would require "attention to causes of individual insecurity and obstacles to realization of the full potential of individuals". In 2012 the General Assembly (GA) adopted a common definition of the human security concept (UN General Assembly, 2012).The 1994 HDR highlighted freedom from fear and freedom from want are two major components of human security. Frankin D. Roosevelt referred in his speech in 1941 on universal declaration of human rights talks about four freedoms these freedoms are : freedom of worship, freedom of speech and expression, freedom from want and freedom from fear (Roosevelt D. Franklin, 1941).Freedom from fear and Freedom from want become the basic principles of human security out of these four freedoms (Rotschild, 1995; Tadjbaksh, 2014).According to 1994 global Human Development Report (HRD) the concept of security has "for too long been interpreted narrowly: as security of territory from external aggression, or as protection of national interests in foreign policy, or as global security from a nuclear holocaust. It has been related more to nation states than to people." The United Nations (UN) Human Development Report (HDR) was more specific, listing seven essential dimensions of human security: Economic security, food security, health security, environmental security, personal security, community security and political security.

\section{Threats to Peace and Security during Covid- 19 Pandemic}

The UN Security Council passed a resolution 2532 on July 2020 111 days after the WHO declared the Covid-19 as a pandemic. The WHO recognised that coronavirus pandemic "is likely to endanger the maintenance of international Peace and Security" (Pobjie E, EJIL 2020). The UN chief told that "The world has entered a volatile and unstable phase in terms of the impact of Covid-19 on Peace and Security". It is the game changer for international peace and security. The enactment of national emergency, complete lockdowns, closed borders, introduction of police checkpoints and restrictions on citizen's movement and speech is similar to warlike 
situation. Across the world, people are using terminology "War against an invisible enemy" to describe efforts to contain the spread of Covid-19 (Silbert C, 2020). The Covid-19 has disturbed our lives in profound and unusual ways. All peoples in the world experience the fear and anxiety about their health and safety. Many people are facing hardships, such as isolation from their loved ones, deaths of their loved ones, elevated risk of poverty, unemployment and homelessness. Moreover, the International tensions are being raised by the disruption in supply chains, food insecurity and rising unemployment leads to increase political unrest. All students are missing school and their education is disrupted. They feel neglected, left out and disillusioned by their prospects in an uncertain world. (Modern Diplomacy, 2020). The conflict between the China and United States (US) over the origin of corona virus and the breakdown of relation between US and WHO has led to endanger the peace and security of the world. This pandemic also highlighted the threats like bioterrorism and cyber attacks on critical data related to Covid19.

The Covid-19 has the great impact on the economy of the world. It has affected the economy of more than 150 countries. The lockdown during Covid-19 pandemic has affected all service sectors like restaurants, banks, food and beverages etc. The Ecommerce sectors also affected due to the pressure of supply chain deliveries. Indian economy is also passing through great recession and highly unemployment. With the increase in coronavirus cases, the government locked down all public and private offices, factories, transport services etc. Recent studies suggest that there are 40 millions job losses (HRD report) in the country in different sectors (Mukherjee T \& Ray N, 2020). The GDP of India is decreased by current financial year (2020-21). The World Bank put it down by $3.2 \%$ while CRISIL put it at $5 \%$ down (Bhattacharya $\mathrm{T}, 2020$ ). The below figure1 shows Covid-19 impact on global economy including India:

\section{Media: Driver of Peace and Human security} Information is the strength and power that can effect on public discourse. Media is the primary source of information. "The Media" refers to "several mediums or channels used in an organised fashion to communicate information to groups of people, as a service to the public" (Howard, 2002). The term media refers to both traditional mass media (TV, Radio, Newspaper etc.) and Social media (facebook, online blogs, twitter, whatsapp etc.) Media plays a very important role in peace building and peace keeping. Media is a powerful tool for communication and socialization (Fonget al., 2019). It has an important effect on perceived public opinion about the reality and it also allows dominant groups into shaping individual's values, attitudes and opinions (Fong et al., 2019; Gitlin, 1980).Media technologies offer opportunities to ordinary people to acquire, educate, inform and to play an active role in democratic societies to make politicians more accountable to the people. The internet in particular has been highlighted in this respect

\section{Global Economic Impact Of COVID-19}

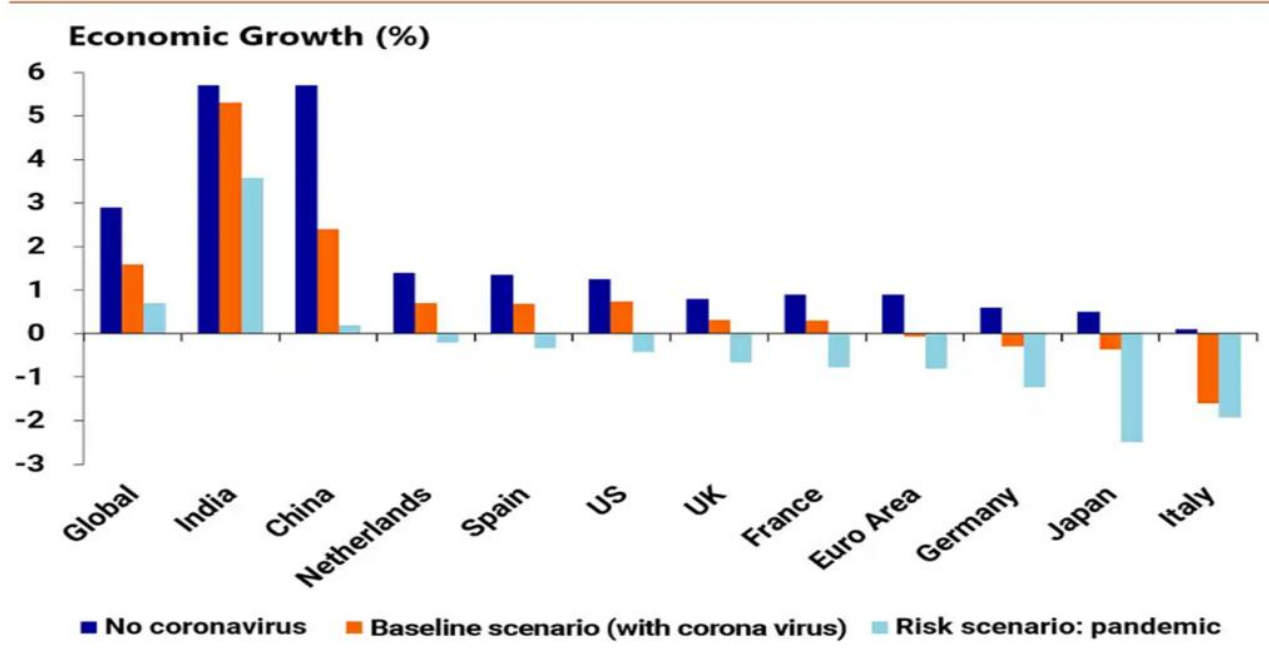

Figure 1: Source: Ranbobank, Macrobond, Bloomberg Quint. 
because it is public sphere that anybody can access usually at little or no cost. Media can revitalise democracy because it gives voice to those who would otherwise go unheard. It is also as an enabler for individuals to gather themselves and take action against social injustices and policies rapidly (Lance Bennett \&Segerberg, 2011).Now these days media is considered as forth pillar of the world, especially for biggest democracy like India.

Not to forget the benefits of media and its role towards peace by imparting education and fast communication that served people to improve their standard of living. On the other hand, media is sometimes distorted, fragmented and biased in many cases. Media sometimes misused for propaganda purposes, to create violence and hatred and tensions (Wolfsfeld \& Gadi, 2004). During any conflict or tension, lack of information make people violent, insecure and easy to manipulate. For this reason United Nations Millennium Declaration stressed the need "To ensure the freedom of the media to perform their essential role and the right of the public to have access to information" (UNMD, 2000).
Anna, 2020). As such every individual also get the same and know what has happening around the world. Everyday hundreds of web channels has spreading rapidly whether that has related to the news, entertainment or for some any other purpose but the main motive behind every channel is to provide real information to the society so that society would progressively grap the knowledge about what is happening around them and also help them to change according to the circumstances. In short it is only the media that can aware the society. Somehow during the covid-19 crisis the role of media is very effective to aware the society against the corona virus pandemic. As the corona virus emerged from China and has spread all over the world which makes the earth like a prison (She J, Jiang j \& Song Y, 2020). In China the agency media is not independent and is under the control of local government. There are only a few news broadcast in China but the same has been run by the government as such no news which is against the China has released by them and the effect is that the whole world did not know the reality what is happening inside the China (Gardner P. at al., 2020). The situation which the world is facing today is

Figure 2: Graphical representation of daily infections and deaths

Source:https://graphics.reuters.com/world-coronavirus-tracker-andmaps/countriesandterritories/india

\section{Media in the Covid-19 Pandemic}

Covid-19 crisis is a biggest threat on peace and human security of the people. It created fear among billions of people. Hundreds and thousands of news channels in the world drive their live telecast for billions of peoples so that more informative news people will get(Paz $\mathrm{R}$ only because of the death of media in China. During the emergence of the corona virus pandemic if the Chinese media aware the world about how pandemic it is, than every country prepares himself to fight against the corona virus pandemic (Jacob JT, 2020). The 
first goal media of every country is the security and peace of his citizens on all levels. In India, state of Kerela reported first SARSCoV-2 positive case on January 30th, 2020. Afterwords the number of cases radically rose. (Kumar Udhaya S, Kumar Thirumal D, \& Priya George C, 2020) According to the press release by the Indian Council of Medical Research (ICMR) on September 17th , 2020, a total of $8,462,080$ infections and 125,562 coronavirus reported in the country and an 46,423 new infections on average each day as shown in the below figure 2 .

Media plays an important role in containing Covid-19 and saves many lives. The media is following the every step during the journey of Covid-19 with headlines, multiple stories and updates across the past few months. Due to the outbreak of Covid-19, more than half of the world is under lockdown which makes a deep impact on our daily lives. People become more dependent on TVs, Mobiles, Internet and social media for information, study and work from home. During lockdown, there is $87 \%$ increase in usage of social media and the social media activity increased by $50 \%$ (Shailvi \& Shambav S, 2020).

Media ensures the awareness and sufficient knowledge about the pandemic among pharmacists to recognize factors and symptoms and influenced their risk perceptions in order to control and prevention of disease (Karasneh R \& Khader Y, 2020). Media is used for the rapid dissemination of follow-up protocols, protection, treatment and allocation of scarce medical equipment to the wider populace (Dhoot R., 2020). Media facilitate the researchers, public health experts, scientists and funding agencies for communication and their responses (Ippolito G, Hui D.S, Ntoumi F \&Zumla A, 2020). Media also used for entertainment, communication with friends and family to reduce boredom, loneliness, isolation and anxiety. Therefore media has becomes a strong recommendation to decrease the psychological impact during Covid-19 (Brooks SK, Webster RK, Smith LE, Wessely S \& Greenberg N, et. Al., 2020). Different media platforms like $t v$, radio, youtube, zoom, whatsaap etc. are widely used for medical education through live, online and recorded videos and webinars. Even during Covid-19 pandemic, there is possibility of arranging discussions, surveys, research projects and multicentre studies through media (Daniel A\& Gonzalez P, 2020).

To forecast the financial impact of Covid-19, researchers developed a real time method that used different media platform which in turn helps to recover from current economic crises. Social media used to chart the economic impact and recovery of businesses in countries that are effected by covid-19 pandemic (Economic Times, 2020). Now during the pandemic, people are looking towards the social media to earn their livelihood through online work from home. Social media provides new opportunities to the people and helps in economic growth (LaHaya Felix, 2018).

Covid-19 pandemic also affect the education system of the world. Education International Organizations records the closure of schools in 188 countries. Now it becomes difficult for many countries to open the school in order to prevent this pandemic. Thus covid-19 becomes disaster if students are not able to get education for any longer(Chinmi, Marta, 2020). Covid-19 pandemic has forced institutions to shift from traditional learning to online learning through media (Abu Elnasr, E Sobaih, Ahmed M \& Hasanein, 2020). Now around 1.5 billion students are studying online through different media platform and lakhs of students are learning in India. Students are being educated through electronic textbooks, variety of online courses, meeting platforms like webex, Google classrooms, zoom etc.(Sisodia Rajesh, 2020). Many tv channels and radio are also broadcasting the live classes in different subjects by experts for the students. Different organization like UGC, NCERT, NCTE, NISHTHA are imparting training to the teachers through media. The teachers are also shifted to social media platforms for teaching learning process. The social media helps them to achieve their course intended learning outcomes (Abu Elnasr, E Sobaih, Ahmed M \& Hasanein, 2020).

\section{Negative Impact of Media}

Media has played a crucial role in dissemination the information, awareness and knowledge about public health. However social media also become a bigger platform of propaganda, exaggeration and falsehood which leads to social unrest and anxiety (Ghosh Rudrani, 2020). The social media creates the panic of pandemic faster than the 
Covid-19 outbreak. Even the panic of social media hits India before the detection of first case of Covid-19(Atre SR \& Kadam AB, 2020).Media provides huge information. Many of them are false information and half-truths as media provides a freedom of choice so every individual broadcast the information according to his choice and interest (Obi-Ani, Chinenye, Mathias \& Isiani 2020). Fake news is forged information that creates panic environment in the society and becomes hindrance in implementing control measures prescribed by the government(Raj, Goswami, 2020).In present scenario there are number of twenty four hour news channels, social media applications and newspapers etc, the journalists compete with each other to create profitable news, sometimes to increase the TRP's they try to sensationalize and spiced the news to attract more viewers. It is seen that Indian users spent most of the time on social media and the pattern of using social media by Indian and Chinese users have converged (Krishnan, 2019). Here the media's reality is away from the truth and is harmful to the foundation of communal peace. So it is very difficult to find authentic information from millions of false information and half-truths. Media is losing the trust of the general public. The media has to avoid doing this and stay on the belief of social responsibility.

\section{CONCLUSION}

The importance of media in creating awareness on political rights that helps people to put in efforts to maintain peace and promoting harmony. Once this crises is over the world will face decisions on the direction of travel, often crises can lead to permanent changes in behaviour. Media play a very important role to aware, to maintain peace and to control this pandemic during Covid-19 crises. Media is becoming more popular day by day. It has become the primary source of getting information about the world. Majority of the people in the world getting information from the different types of media platforms. Media provide both the positive or negative news which create sensation which increase TRP and viewership. Positive news leads to maintain peace and security of the society but negative news leads to confusion and insecurity among people. By this study it is proved that media has done a fabulous job tomaintain peace and security of people during the Covid-19crisis. So the information of reliable sources such as government health authorities and specialist experts to be trusted, while the unreliable information not to be circulated before evaluating them. It is suggested that there is a need to create awareness and education, So that media can be used in positive way to build trust, better adherence to pandemic control measures and cooperation to maintain peace and human security.

\section{REFERENCES}

Acharya, A. (July 2007). "The emerging Regional Architecture of world politics". World Politics 59. no. 4: 630.

Alianto, H., \& Chandra, Y. U. (2017, November). The smartphone for disseminating of fake news by the university students game player. In 2017 International Conference on InformationManagement and Technology (ICIMTech). pp.14-18.

Ayedee, N., Manocha S. (2020). Role of Media (Television) in Creating a Positive Atmosphere in COVID-19 during Lockdown in India http://dx.doi.org/10.2139/ssrn.3605514

Blatz,W.,Ernest.(1967). Human Security: Some Reflections. London University Press. London.

Chen, N., Zhou, M., Dong, X., Qu, J., Gong, F.,Han, Y., Qiu, Y., Wang, J., Liu, Y., Wei, Y., Xia, j., Yu, T., Zhang, X., \& Zhang, L. (2020). Epidemiological and Clinical characteristics of 99 cases of 2019 novel coronavirus Pneumonia in Wuhan, China: A descriptive study. The Lancet, 395, 507-513. https://doi.org/10.1016/S01406736(20)30211-7

Editor. (2020a) COVID-19 Impact Vedantu to Provide Free Access to Live Classes, Study Material, Tests, Assignments- The Hindu BusinessLine.

Editor. (2020c). Education In The Times Of COVID-19 And How To Keep Up With Studies-The New Indian Express.

Galtung, J. (1996). The Struggle for Peace. . New Delhi: Sage Publication. pp. 56-56.

Galtung, J. (1996). Peace by Peaceful Means: Peace and Conflict, Development and 
Civilization Thousand Oaks. CA: Sage Publications.

Galtung, J. (2008). 50 Years. 100 Peace and Conflict Perspectives. Transcend University Press.

Hamelink, C. J. (2008). Media and Conflict: Escalating Evil. Boulder: Paradigm Publishers.

J. T. Wu. K. Leung, and G. M. Leung, (2020). "Nowcasting and forecasting the potential domestic and international spread of the 2019-nCoV outbreak originating in Wuhan, China: A modelling study," Lancet, vol. 395, no. 10225 . pp. 689-697

Jagan Mohan, M.(2020). Travel and Tourism Industry in India, Statistics and Facts. https://www.statista.com/topics/2076/t ravel-and-tourism-industry-in-india/

https://www.weforum.org/agenda/2020/03 /a-visual-history-of-pandemics

Krishnan, V. B. (2019, August 21). How much time do Indians spend on social media? The Hindu. Retrieved from https://www.thehindu.com/news/natio nal/ how-much-time-do-indians-spendon-socialmedia/article29201363.ece Lazer, D. M. J., Baum, M. A., Benkler, Y.,

Lobato, E., Powell, M., Padilla, L., Holbrook C.,(2020). Factors Predicting Willingness to Share Covid-19 Misinformation. https://doi.org/10.3389/fpsyg.2020.5661 08

Morgenthau, H. (1948). Politics Among Nations: The Struggle for Power and Peace. Alfred, A. Knopf. New York.

Narula, S. (2012). Mass Communication \& Journalism Models of Structuring Peace and Gandhi in Modern Democratic System. Journal of Mass Communication $\mathcal{E}$ Journalism, 2(5), 5-7. https://doi.org/10.4172/21657912.1000e117

Qiu, W., Rutherford, S., Mao, A., \& Chu, C. (2017). The Pandemic and its Impacts. Health, Culture and Society, 9, 1-11. https://doi.org/10.5195/hcs.2017.221

Sambhav,S. (2020). Role of Mass Media Communication During Pandemic.WWW.IJCRT.org.

Thomas,Caroline(2000). Global Governance, Development and Human Security: The Challenge of Poverty and Inequality. Pluto Press. London.

Tehranian (ed.), Majid(1999).Worlds Apart: Human Security and Global Governance. New York.London .

United Nations Development Report (UNDP) (1994).HumanDevelopment Report 1994: New Dimensions of Human Security. New York.

Wilson, ME. Chen, LH(2020).Travelers Give Wings to Novel Coronavirus (2019-nCoV), J Travel Med.

Wolfsfeld, G (2004).Media and the Path to Peace. P.8-10

Waltz, N., Kenneth. (1979). Theory of International Politics.New York. AddisonWesley.

Yusuf, I., Yahaya, S., Qabil, S. (2015). Role of Media in Portraying Ebola in and outside Africa. Journal of Tropical Diseases, 03 (01). 